\title{
DEVELOPING AND IMPLEMENTING A HIGH SCHOOL SIMULATION COURSE TO PROVIDE RIGOR AND RELEVANCE TO THE CURRICULUM
}

\author{
Beverly Biel Kuch \\ Cuyahoga Valley Career Center \\ 8001 Brecksville Road \\ Brecksville, O.H. 44141, U.S.A.
}

\begin{abstract}
This paper discusses the chronology of events leading to the development of one of the nation's first high school simulation courses using Arena ${ }^{\circledR}$ software. Through the efforts of a partnership between Cuyahoga Valley Career Center (CVCC), North Royalton High School (NRHS) and Rockwell Automation, specialists in mathematics, careertechnical education and simulation collaborated to develop and implement a high school course in alignment with academic and career-technical standards, containing the rigor and relevance required of a $21^{\text {st }}$ century high school. Included in the discussion is the need for high school reform, the rationale for the course, philosophical barriers, curriculum development and related standards. Examples are given of class projects, including student culminating projects used for assessment and grading.
\end{abstract}

\section{INTRODUCTION}

A unique partnership was formed to introduce computer simulation instruction at the high school level. In 2004, upon the discovery of software that could stimulate student interest in the topic - Rockwell Automation's Arena - a study into the viability and benefit of such a course began.

Expectations about what students learn in high school must be raised dramatically to produce a new generation of scientist and engineers (Achieve, Inc. 2004). Most high school students have no desire to pursue engineering and do not even have sufficient general math and science skills. Academic standards are not challenging enough, and curriculum is outdated (Johnson et al. 2006). Integrated programs are needed - core academic subjects coupled with a foundation in work skills and applications. Students should be able to see the relevance of instruction. In order to accomplish these changes, instruction must be rigorous and teaching philosophies must change.

This paper discusses the history of the development of one of the first full-semester high school simulation courses from conception in 2004 to implementation in the winter semester of the 2006-07 school year at NRHS, an associate school in the CVCC joint vocational district in northeast Ohio.

\subsection{Background}

During a demonstration of the Arena software at a Cleveland State University seminar for educators in 2004, the author recognized a connection between Arena's animation graphics and the graphics of computer games such as SimCity $^{\circledR}$, and RollerCoaster Tycoon ${ }^{\circledR}$, popular among students. After the seminar an idea was generated to bring this technology into the high school. The original plan involved an exploration unit. The ultimate goal was an elective course in the technology education department or an advanced mathematics elective in the math department of the high schools served by CVCC. The course would be in alignment with the philosophies of high school reform and with the academic standards currently recommended by the Ohio Department of Education (ODE). It was postulated that exposure to professional software packages with features similar to games currently enjoyed by high school students would stimulate them to consider careers in science and technology by illustrating the relevance of their learning.

\subsubsection{Ohio Joint Vocational Districts and CVCC}

Of the 92 planning districts providing career-technical education for secondary and adult students in Ohio (ODE 2007), Cuyahoga Valley Career Center is a lead careertechnical district located in Brecksville, Ohio. It has eight associate/member schools whose students may attend the career center for comprehensive studies in a career field during their junior and senior years of high school. The school districts served by CVCC are: BrecksvilleBroadview Heights City, Cuyahoga Heights Local, Garfield Heights City, Independence Local, Nordonia Hills City, North Royalton City, Revere Local, and Twinsburg City. 
Students attending the career center specialize in a career field while completing academic coursework at their home school. In their freshman and sophomore years, many of these students take a foundation type elective course, which provides instruction in the core principles related to this career field.

\subsubsection{Mission and Objectives of Career Pathways}

The mission of the Career Pathways department at CVCC is to introduce students to career options with hands-on projects in the classroom and to provide professional development opportunities to their high school instructors, assisting them in the development of "real-world" lesson plans. A simulation course using Arena software in the technology education foundation classroom, with support from mathematics teachers, was determined to be precisely the type of rigorous, relevant instruction needed to demonstrate the application of students' math and technology skills and to see the potential of a future career.

\subsection{Forming Partnerships}

To introduce simulation at the high school level, interest and support had to be generated both in industry and at the administrative and instructional levels of the targeted schools. In 2004, with the assistance of Kent State University, Career Pathways presented an Arena workshop for associate teachers in its districts to determine interest level in the project.

\subsubsection{Partnering with Rockwell Automation ${ }^{\circledR}$}

In 2004, the concept was presented to Tom Hayson, Arena Sales Manager, and an early champion of the project, who offered the Arena Research Edition License to the program at no cost. Hayson describes university instruction as a seed for industry use. He saw the potential of high school instruction becoming a seed for university instruction. This relationship continues today with support in the form of visits to the students, and other technical assistance.

\subsubsection{Partnering with North Royalton High School}

The simulation course concept was presented to associate school curriculum directors in 2005. North Royalton High School agreed to work with CVCC to develop the course and offer it in the 2006-07 year. Summer training was provided by Rockwell Automation trainer C. Jurishica in 2005 for teachers selected to develop the course curriculum. The training was funded by an education grant.

\section{RATIONALE FOR TEACHING SIMULATION IN HIGH SCHOOL}

\subsection{The Call for High School Reform}

In order for our nation's high schools to succeed and produce students ready to complete in the $21^{\text {st }}$ century, a new 3R's will be required. Replacing reading, 'riting and 'rithmetic, are rigor, relevance and relationships (Gates 2007).

One-half of our nation's students drop-out of high school (Bridgeland et al. 2006). Of those who graduate and go on to college, $50 \%$ will need remedial coursework, $40 \%$ at 4 year institutions and $63 \%$ at 2 year institutions (Venezia et al. 2003) . To remedy this situation, leaders in business, industry and education are supportive of the new 3R's. Coursework must be challenging and it must be relevant to the students' lives. Students need adults to mentor them to success. Even dropouts, when interviewed, state that they would have stayed in school had the adults in their lives pushed them harder. (Bridgeland et al. 2006). Many systems are in place today to do just that, KIPP (Knowledge is Power Program) Schools, High Tech High Schools, High Schools That Work, STEM (science, technology, engineering and mathematics curriculum) schools, any many more. These schools have high expectations and are results oriented. Pre-Engineering, Science and Technology are integrated into the curriculum.

\subsubsection{High School Best Practices}

Strategies for leading high school reform include high quality work to engage the student, allowing them to develop critical thinking and problem-solving skills. Curriculum should connect to real-world applications, allowing students to connect their education to their future careers (National Association of Secondary School Principals (NASSP) 2004).

\subsubsection{Reform curriculum}

There is a need in today's workplace for high school graduates who have mastered mathematics, science and technology. Curricula which respond to this need are being adopted in reformed high schools around the country and supported by departments of education, business and industry.

The "Integrated Science, Mathematics and Technology Curriculum" series, developed by a partnership of Oregon businesses and teams of math, science and technology education teachers from Oregon schools is one example, calling for an applied approach, with input from local business and industry, strong communications skills, opportunities for teamwork and individual work, and creativity. Math, science and technology academic standards are integrated 
and social and political factors discussed (Oregon State University 1993).

Stretch learning is another method of rigorous and relevant method where learning is demonstrated beyond minimum requirements. (Daggett 2006).

There are some barriers to be overcome when developing rigorous coursework at the high school level.

\section{PHILOSOPHICAL BARIERS}

It was difficult to interest educators in the simulation course due to current pedagogies.

\subsection{College Professors}

Engineering colleges seek students with application experiences as a foundation for college level instruction. Engineers say more classes are needed that apply math, science and technology using hands-on problem solving skills and computer programming (Mativo et al. 2007).

College professors must understand that proposed rigorous coursework - in this case a high school simulation course using Arena - is not meant to duplicate what is currently taught at the post-secondary level. Teaching simulation in high school will introduce and prepare, leading to a college student capable of succeeding at a higher level. A high school student will not have the mathematical ability to delve into all the levels of the software, but will operate at a more basic level.

This barrier was experienced by the author as she attempted to generate interest in forming partnerships to develop a high school simulation course. Professors currently teaching Arena courses in the industrial engineering and management systems departments of two local universities initially felt the material was too advanced for high school students to grasp. A partnership was finally development with Kent State University to develop and present a teacher workshop demonstrating basic examples of Arena problems in an attempt to interest high school teachers in the potential of a unit and ultimately a course in simulation at their schools.

\subsection{Current High School Teachers and Their Roles}

\subsubsection{The High School Mathematics Teacher}

Math theory is taught in high school. Teachers are not often trained in related problem solving and do not have sufficient skills to use the computer as a resource to solve complex problems (Franklin and Gould 2001). In this project, the author found that math teachers are not comfortable instructing in an area where today's computerliterate student may surpass them in knowledge.

\subsubsection{The High School Statistics teacher}

Teachers of statistics typically have no real training in their subject during their college experience. (Franklin and Gould 2001). They should use computational software but are not trained in its use (American Mathematical Society 2001). Neither are they trained in applications of data taking and analysis, necessary for complete statistics instruction (Association of Mathematics Teachers 2006).

\subsubsection{The High School Technology Education Teacher}

Technology education teachers are better prepared to deliver a balanced approach to theory and applications. Students develop skills with many types of technology. Tech Prep education, which can provide articulation credit to local colleges and universities, develops a student with proficiency in math, science, communication and technology, with employability skills. Tech Prep teachers often work in collaboration with external partners (National Centers for Career and Technical Education 2007). During the development of our simulation course, we saw that the technology education teacher would not be able to deliver sufficient mathematics rigor. It would be necessary to add a math teacher to provide that rigor to complete the instruction.

\subsection{The Reform Redefined High School Teacher}

Teachers in reformed high schools should be willing to redefine their role from instructor in front of the classroom to coach and facilitator providing leadership to allowing students to become more active and involved in their education (NASSP 2004). These teachers will collaborate with others in the educational community, seeking partnerships and other forms of support. Rapidly changing technology requires higher expectations of educators. Rich problems representing significant mathematics connected to the curriculum are needed in high schools today. Rich problems utilize mathematical processes, with multiple layers of complexity, multiple solutions and strategies (Carlson 2006). The students are the workers and decision makers. Students develop skills: confidence, cooperation, communication, persistence, inventiveness and flexibility and have enthusiasm for learning.

\subsubsection{Teaching Statistics in $21^{\text {st }}$ Century Schools}

These teachers must be willing to accept that today's computer literate student will likely surpass their knowledge and accept their newly defined role as a coach. Their instruction will still be required to assure that sound data collection methods and proper statistical models are chosen. Statistics teachers need to prepare students to collect and 
analyze data and to use the computer in real-world applications (Franklin and Gould 2001).

\subsubsection{Career and Technical Education Coupled with Academic Core Subjects}

The ideal $21^{\text {st }}$ century school contains integrated programming. All students are prepared with high quality instruction in the core academics, meeting stringent graduation requirements. In addition, these core academics are now relevant because the student has been given ample opportunities for hands on experiences and career exploration. Currently, tech prep programs offered at career centers such as CVCC deliver this type of programming.

\subsection{Students and Parents}

While leaders believe that the nation does not graduate enough scientists and engineers to maintain the competitiveness of the United States, most families believe their children receive a good education in math and science. While parents believe high school is more challenging now than when they attended and that their children are prepared for college, leaders say that our academic standards are not challenging enough (Achieve, Inc. 2004). When asked, nearly $40 \%$ of students say they would be "really unhappy" in a math or science career (Johnson, et al. 2006).

The ODE cites the lack of participation in rigorous curriculum in the $11^{\text {th }}$ and $12^{\text {th }}$ grades as a growing problem (Shibley 2006). The phenomenon is referred to a senioritis or senior slack. There are now efforts in place in $21^{\text {st }}$ century schools to curb the problem, some even going so far as to forbid slacking (Southern Regional Education Board 2004). Our goal of a senior mathematics elective in simulation is in alignment with these new trends.

\section{RATIONAL FOR SIMULATION COURSE DEVELOPMENT AT A CVCC ASSOCIATE HIGH SCHOOL}

Simulation education, to the author, is analogous to computer aided design education and in a basic, introductory form can be introduced into high school and meet current academic standards as well as the criteria for a $21^{\text {st }}$ century school.

Computer aided design (CAD) is currently taught in high school and even in middle school. In CAD's historical timeline, the original programming was first developed at MIT's Lincoln Lab in the 1950's; the first commercial product was introduced until 1969; in 1987 the first certified national courses of study began at the London Institute; college instruction became commonplace in the mid80's and by 1992 Autodesk Education began in the high school (Bozdoc 2006).
Arena is used in industry and taught in universities. By teaching Arena in high school we can reach students early, enabling them to consider simulation as a career choice. Since most post-secondary schools offer courses designed to teach specific simulation languages and their uses, the selection of specific simulation software - Arena -- was appropriate for a high school course.

Coincident to our project, an Oklahoma high school student used Arena to simulate a traffic flow problem, a project which earned him a first place finish in the city's science fair, allowing him to advance to an international competition in Romania, where he won a gold medal (Dove Academy 2007). This success story aided us in convincing our desired partners of the capabilities of today's high school students.

\section{DEVELOPING THE HIGH SCHOOL SIMULATION COURSE}

\subsection{Identification of Target Student Audience}

It was necessary to define the proper student who would take the simulation course. Hayson stated by email to Kuch that while the underlying technology of Arena, stochastic analysis, relies on high level mathematics, it can be simplified for younger students to a discussion of bell curves and Monte-Carlo variability.

\subsubsection{Pre-requisite High School Mathematics Courses and Grade Taken}

Prerequisite requirements needed to be determined to ensure that the students would have the proper math background. The target student will have mastered the concepts of Geometry and Algebra II. By the time these courses have been completed the student will have had some experience with data analysis and probability, and solved problems dealing with uncertainty. Most mathematics students have taken Algebra II by the end of the sophomore year and advanced students by the end of the freshman year. Based upon this population, the course was opened to grades 10-12 with the prerequisite of completing Geometry or Integrated Math (Algebra II). When the course opened for the first time I January of 2007, 25 high performing students enrolled.

\subsection{Standards Integration}

Any new high school course must be aligned to standards. The Ohio and national mathematics standards applicable to our proposed simulation course (ODE 2006) are shown in the following table: 
Table 1: Applicable Ohio and National Council of Teacher Academic Standards

\begin{tabular}{|l|l|}
\hline \multicolumn{1}{|c|}{ Standard } & \multicolumn{1}{|c|}{ Description } \\
\hline $\begin{array}{l}\text { Number, Number Se- } \\
\text { nse and Operations } \\
\text { Standard (Ohio) }\end{array}$ & $\begin{array}{l}\text { Demonstrate number sense, un- } \\
\text { derstand number systems, opera- } \\
\text { tions and relationships }\end{array}$ \\
\hline $\begin{array}{l}\text { Patterns, Functions } \\
\text { and Algebra Standard } \\
\text { (Ohio) }\end{array}$ & $\begin{array}{l}\text { Use patterns, relations and func- } \\
\text { tions to model, represent and } \\
\text { analyze problem situations in- } \\
\text { volving variable quantities. } \\
\text { Analyze, model and solve prob- } \\
\text { lems using various representa- } \\
\text { tions }\end{array}$ \\
\hline $\begin{array}{l}\text { Algebra Standard } \\
\text { (National Council of }\end{array}$ & $\begin{array}{l}\text { Use mathematical models to rep- } \\
\text { resent and understand quantita- } \\
\text { tive relationships; analyze } \\
\text { change in various contexts }\end{array}$ \\
\hline $\begin{array}{l}\text { Data Analysis and } \\
\text { Probability Standard } \\
\text { (Ohio) }\end{array}$ & $\begin{array}{l}\text { Pose questions; collect, organize, } \\
\text { represent, interpret and analyze } \\
\text { data to answer questions; de- } \\
\text { velop and evaluate inferences, } \\
\text { predictions and arguments based } \\
\text { on data. }\end{array}$ \\
\hline $\begin{array}{l}\text { Pata Analysis and } \\
\text { Probability Standard } \\
\text { National) }\end{array}$ & $\begin{array}{l}\text { Formulate questions involving } \\
\text { data; collect, organize, and dis- } \\
\text { play relevant data; select and use } \\
\text { appropriate statistical methods to } \\
\text { analyze data; develop and evalu- } \\
\text { ate inferences and predictions } \\
\text { based on data; understand and } \\
\text { apply basic probability concepts. }\end{array}$ \\
\hline $\begin{array}{l}\text { Mathematical Process } \\
\text { Standard (Ohio) }\end{array}$ & $\begin{array}{l}\text { Use mathematical processes and } \\
\text { knowledge to solve problems; } \\
\text { apply problem solving and deci- } \\
\text { sion making techniques; com- } \\
\text { municate mathematical ideas. }\end{array}$ \\
\hline
\end{tabular}

\subsection{Teacher Identification}

CVCC associate school teachers were given two opportunities to experience and evaluate the Arena software as a tool for high school instruction.

\subsubsection{Arena Workshop and Teacher Training}

A one day workshop was developed with the assistance of Kholekile Gwebu, who, at that time, was a $\mathrm{PhD}$ candidate in the Management and Information Systems Department at Kent State University. He holds a Bachelor of Commerce Degree from the National University of Lesotho, Africa and an MBA in Management and Information Systems from Kent State University.

Technology education, mathematics and science teachers in the eight CVCC associate districts were invited to attend the workshop offered by Career Pathways in February, 2004 with the goal of providing a lesson plan specifically developed for high school students. The material was modified by Gwebu to be used at the secondary level .

Upon completion of the workshop, some of the teachers were interested in teaching simulation, but it became apparent that a lesson plan would not provide sufficient time to treat the subject matter. It also became apparent that additional teacher training would be required.

\subsubsection{Additional Teacher Training}

In 2005, selected NRHS teachers selected to develop the course curriculum were given an additional 3-day training session conducted by C. Jurishica, Rockwell Automation trainer. In the summer of 2006, R. Wells, technology education teacher from NRHS who would instruct the course, participated in a week long teacher externship at Rockwell Automation's Mayfield, Ohio offices, supplementing his knowledge in preparation for course development and instruction.

\subsection{Simulation Course Curriculum}

Curriculum was developed by Wells, primarily using lessons from the teacher training workbook (Rockwell Automation 2005). He incorporated data collection and analysis by writing a real world lesson to solve a problem at a local spring manufacturing company. Finally, the students designed their own culminating project which was used for course assessment.

\section{EXAMPLES OF COURSE PROJECTS}

The students in this class had never before been exposed to simulation and had to start at the very beginning. Concepts and terminology, such as variables, entities, attributes, seize, delay and release, were defined. Flowcharting was introduced. Students learned to define the parameters of a simulation run, such as the run length and number of replications. The available reports and their use were also explained.

\subsection{Introductory Lessons}

The coursework began with an introduction to basic process modules with an emphases on learning to use the tools to create simulations taken from the Rockwell Automation teacher training handbook.

\subsubsection{Auto Loan Part 1 Simulation}

The Auto Loan Part 1 problem was presented. This simple simulation shown in Figure 1, utilized a create module, three process modules, and a dispose module to simulate a 
typical auto loan processing center. All flowcharts depicted illustrate the complexity of the models studied and developed by the high school students, and as such module descriptions themselves are not critical.

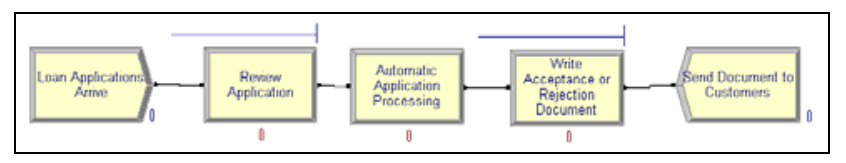

Figure 1: Auto loan part 1 flowchart

While simplistic in nature, the problem allowed the students to grasp the underlying concepts of process flow, system constraints, queuing and variability using the Arena terminology of entities, resources, and seize, delay, release. After creating the flowchart, the run set-up parameters introduced students to methods used to run a simulation.

\subsubsection{Auto Loan Part 2 Simulation}

After simulating a very basic problem, the students upgraded the model to include the physical process of rejecting incomplete applications after review. Students were able to add this new level of detail through the use of variables and the Assign and Decide modules. During this revision, the students also learned to add an animation object. Figure 2 shows the upgraded flowchart.

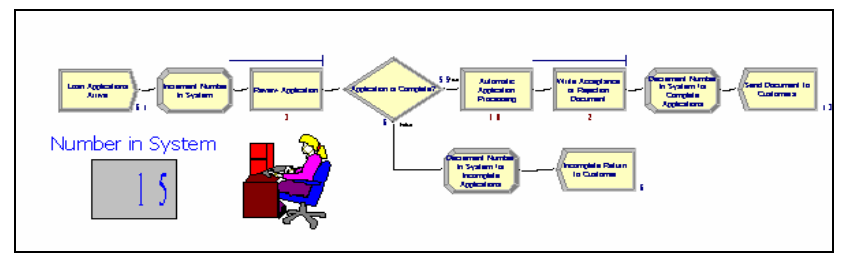

Figure 2: Auto loan part 2 flowchart

\subsubsection{Toy Paint Shop Simulation}

After mastering the basic building blocks of the simulation techniques used in Arena, the students moved on to a more complex problem. To keep the enthusiasm of the high school student, the simulation of a painting process in a toy manufacturing company was chosen as a project the students could understand and to which they could relate.

In this process the students began to understand the business and financial reasons for simulating potential changes in an industrial process.

In the toy paint shop problem statement, the students are asked to evaluate the current process, make changes to increase output, and test those changes, looking for bottlenecks. The system handles two different toy parts from entry to the process in the preparation area, to the paint booth, through inspection, and finally to where they exit the system.
In this simulation, the students are introduced to more powerful aspects of the program. Further understanding of the Assign, Seize, Queue, Delay and Release concepts are achieved. Additionally, the complexity of real world machine maintenance is included in the model. Students use the Arena Failure spreadsheet to model this level of detail to the model. A deeper grasp of basic process mapping is developed as the students use the Decide module at the inspection process to model good vs. bad toys as shown in the flowchart depicted in Figure 3.

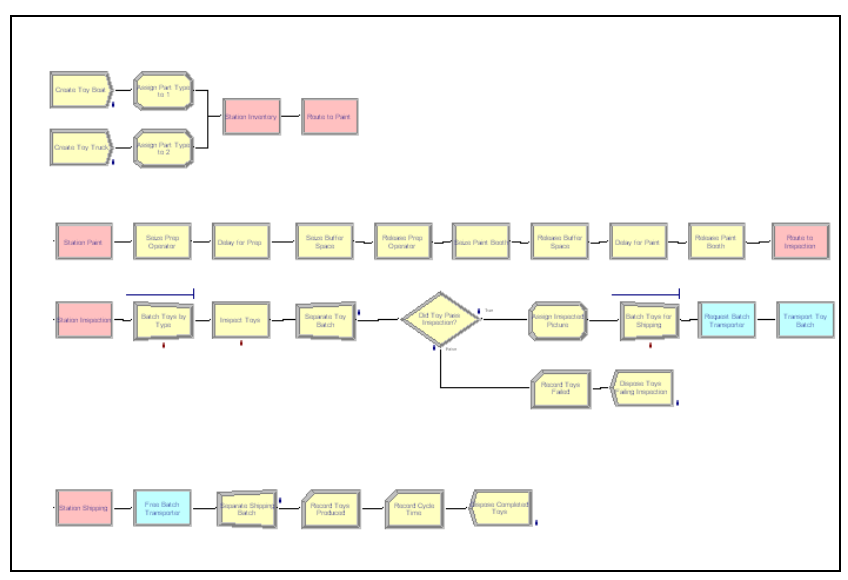

Figure 3: Toy Paint Shop flowchart

\subsubsection{Spring Manufacturing Facility Simulation, Including Data Collection and Analysis}

After completing basic examples, Wells, course instructor, developed a real-world lesson plan. Students in Figure 4 are shown working on this lesson in their classroom.

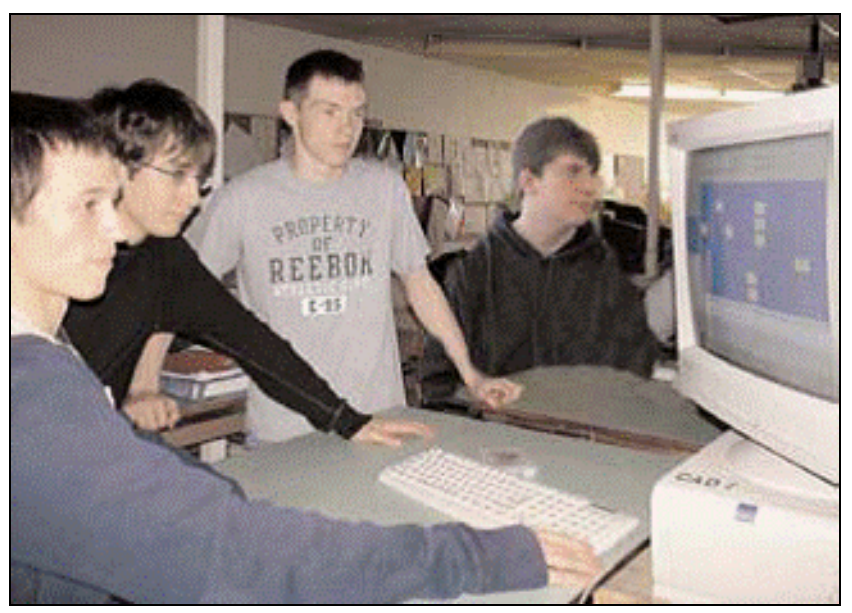

Figure 4: Students simulate a process improvement

While on a day-long field trip, students were asked to observe and collect data on the entire operation of a local spring manufacturing facility, from raw material acquisi- 
tion and storage, through the different processes involved in the manufacture of a spring (heat treatment and deburring, for example), to packaging and shipping. They also observed the quality assurance and sales functions. They were then asked to simulate the process, suggesting an improvement. The process simulation flowchart of one student is shown in Figure 5.

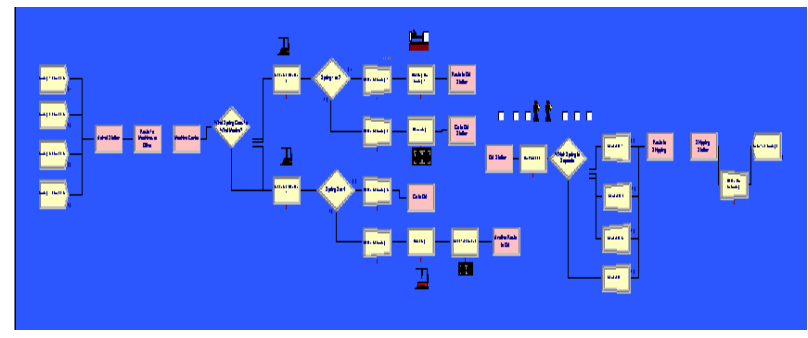

Figure 5: Spring manufacturing facility flowchart

\section{EXAMPLES OF STUDENT CULMINATING PROJECTS}

As a method of assessment, a culminating task should embody the standards and demonstrate the student's mastery of the topic. The project should encompass a problem and its solution and not merely be a sample of the student's work. Students were allowed to design their problem and provide a solution using simulation. The following examples show culminating projects from the first offering of the simulation course at North Royalton High School.

\subsection{Lunchroom - Emily Lynn \& Ryan Orr, juniors}

The two lines in the NRHS cafeteria back up during lunch periods. Emily and Ryan worked together to resolve this problem. The students gathered data during lunch periods, and developed a flowchart to run the simulation. They determined the bottleneck could be resolved by moving the registers and adding a third cashier as shown in Figure 6.

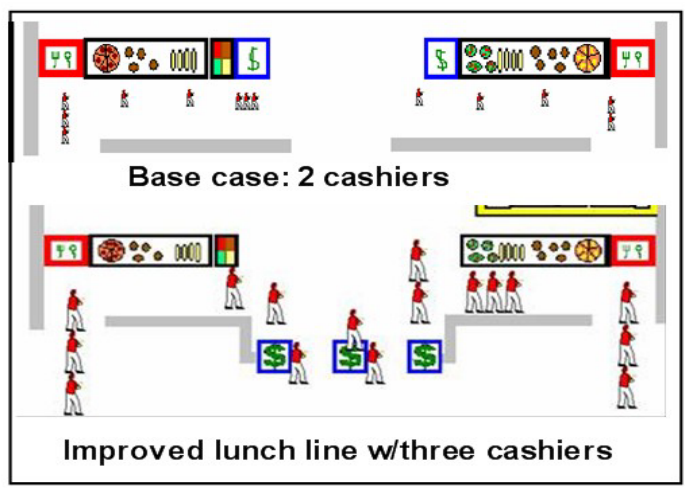

Figure 6: Cafeteria animations - Lynn and Orr
Students were assessed on proper representation of the event, data gathering and problem solution.

\subsection{Parking lot simulation- Kevin Veverka, senior}

At afternoon dismissal, the exiting buses and students vehicles cause traffic delays both in the parking lot and on the two major roads bordering the school. Kevin took data relevant to this bottleneck such as the length of time it took to exit the lot, and the number of cars backing up on the city roads. His flowchart is shown in Figure 7 and his animation in Figure 8. Kevin added a clever component to his project, overlaying the animation over an arial view of the school and surrounding roads. In Figures 9 and 10, the traffic backups at the exits from the school are shown, highlighted by yellow circles. Kevin found that a traffic light at the north exit, timed with the light at the major intersection would solve the bottleneck. He was graded in the same manner as the Lynn-Orr project.

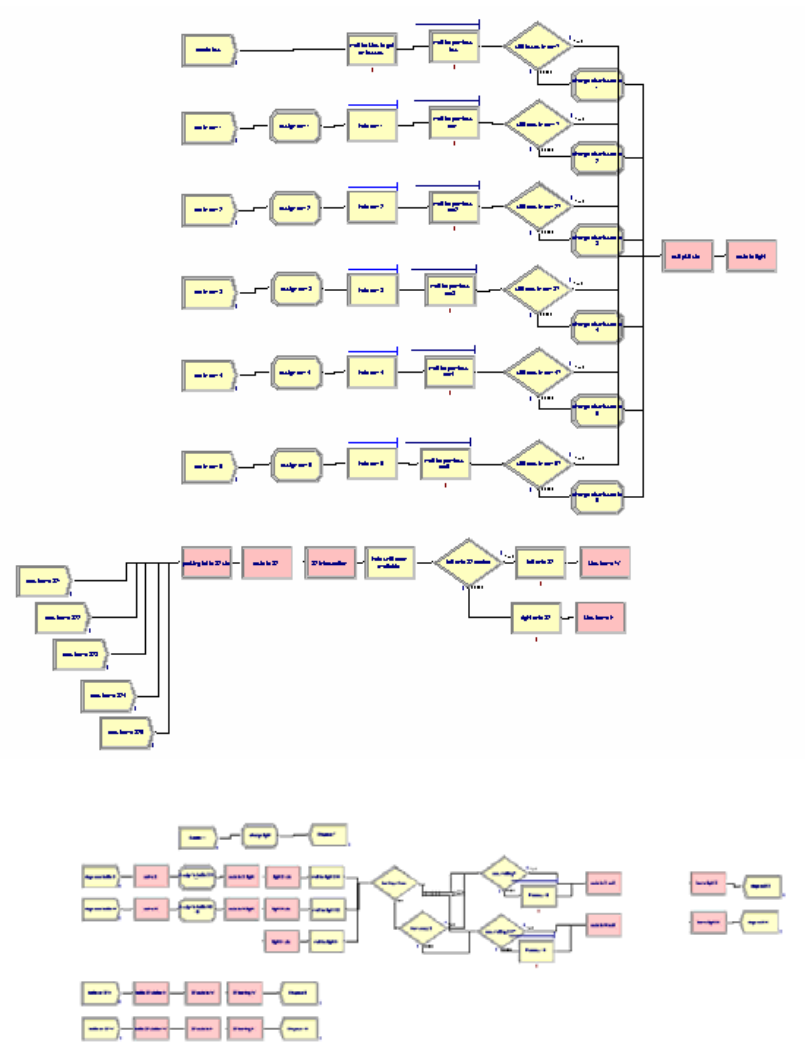

Figure 7: Parking lot flowchart - Veverka 


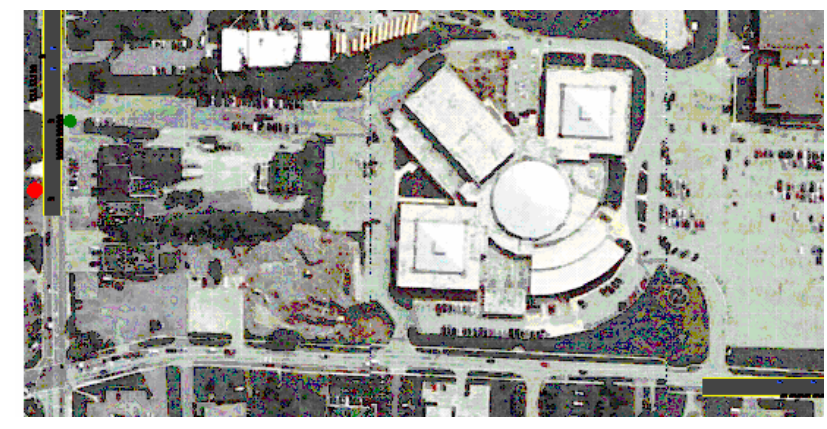

Figure 8: Parking lot animation - Veverka

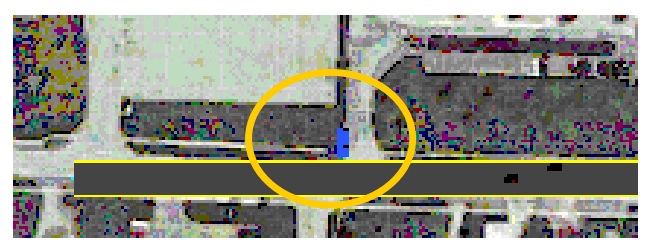

Figure 9: West exit traffic back up - Veverka

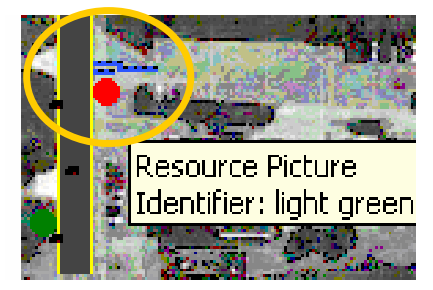

Figure 10: North exit traffic backup - Veverka

\section{WHERE DO WE GO FROM HERE?}

CVCC would like to expand the course offerings to other schools in the district. In 2006, a math teacher at Nordonia Senior High School participated in a week-long teacher externship program, paid for by CVCC. The week was spent at Rockwell Automation's Mayfield, Ohio offices, learning about Arena with the possible goal of adding an advanced mathematics elective at her high school.

In an ideal world, the course would be taught by a team of a technology education and a mathematics teacher, skilled in probability and statistics. Without the math teacher, the current course did not provide the mathematical rigor desired. Due to financial constraints, a critical factor in the decision to add a course is a sufficient number of students, meeting a student/teacher ratio that results in a favorable cost/benefit ratio. Unfortunately, team teaching typically does not have such a ratio.

The current placement in the technology education department must be changed to continue to attract targeted high performing students. An elective, rigorous or not, must fit within the students goals: admission to the college of his or her choice. Today, college admissions departments are looking for rigor. An advance mathematics elec- tive will carry more weight in college acceptance than a technical education elective. While to an outsider, this may seem like semantics, credit in a discipline can only be granted if a teacher holds the proper certification. Therefore, in order to give a math credit, one must have a course taught by a mathematics certified teacher, a credential which a technology education teacher does not hold. Today's students are sophisticated in their course selection. While the initial course offering was filled and popular, enrollment is currently lagging. The course needs to be relocated to the math department which will require additional teacher training and a philosophical shift on the part of the math teachers.

In order to provide the best instruction, partnerships with industry could help provide the financial assistance to train teachers, allow a smaller class size, or to implement the preferred team teaching approach.

Future discussions with career-technical instructors and administrators are recommended to determine interest in simulation course programming at the career center, as a preparatory course for existing Arena instruction at local 2and 4-year institutions, with the potential of articulation credit.

This paper and subsequent presentation at the 2007 Winter Simulation conference will demonstrate the success of NRHS students and stimulate discussion to add similar simulation course offerings, providing rigor and applied instruction at the high school level.

\section{ACKNOWLEDGMENTS}

The author wishes to thank all of the people involved in the development of the Arena simulation high school course for their support. The following organizations and their staff deserve thanks: The Cuyahoga Valley Career Center, Rockwell Automation, North Royalton City School District, and Kent State University, Management Systems Department. In particular, Mr. Russ Wells, NHRS Technology Education Teacher and Mr. Rich Evans, Curriculum Director at North Royalton City Schools; Mr. Tom Hayson Carley Jurishica and Dave Sturrock at Rockwell Automation; and Dr. Celena Roebuck at CVCC. In addition, the author would like to posthumously thank Dr. Elizabeth Puchowicz, whose vision and support enabled this project to succeed. Deserving special recognition are the 25 students in the first computer simulation class at NRHS..

\section{REFERENCES}

Achieve, Inc. 2004. Ready or not - creating a high school diploma that counts. The American Diploma Project, Washington, D.C.

American Mathematical Society. 2001. Conference Board of the Mathematical Science issues in mathematics education, Vol. 11, The mathematical education of 
teachers, American Mathematical Society, Providence, R.I.

Association of Mathematics Teachers. 2006. Preparing teachers to use technology to enhance the learning of mathematics, Association of Mathematics Teacher educators. Available via $<$ http: / / www . amte. net/Approved\%20AMTE $\div 20$ Technology 20 Position 20 Paper.pdf $>$ [accessed June 26, 2007].

Bozdoc, M. 2006. The history of CAD, Available via <http://mbinfo.mbdesign. net/CADHistory.htm> [accessed June 26, 2007].

Bridgeland, J.M., J.J. Dilulio, Jr., and K. Burke-Mouson. 2006. The silent epidemic: perspectives of high school dropouts, Civic Enterprises, L.L.C, Washington, D.C.

Carlson, A. 2006. What makes a problem rich? From: The real power standards: alias the forgotten standard, Ohio Department of Education, Columbus, $\mathrm{OH}$.

Daggett, W. 2006. The skills gap: what it is and how to close it. International Center for Leadership in Education, Inc., Rexford, NY.

Dove Academy. 2007. Brochure. Available via <http://www.dsaokc.org/brochure/2006 $\div 2001 \div 2024 \div 20$ brochureWeb0607\%206.125 x9.25.pdf> [accessed July 2, 2007].

Franklin, C. and R. Gould. 2001. Teaching statistics to high school teachers. Working Group Session \#10, National Summit on the Mathematical Education of Teachers, Conference Board of the Mathematical Sciences, Providence, RI.

Gates, B. 2007. The 3r's solution. Available via <http://www.gatesfoundation.org/Unit ed-

States/Education/RelatedInfo/3Rs_Sol ution. htm> [Accessed June 26, 2007].

Johnson, J., A. M. Arumi, A. Ott, A. and M. Hamill Remaley. 2006. Reality Check 2006: Are Parents and Students Ready for More math and science? Public Agenda, New York. N.Y.

Mativo, J., D. Rouch, D. A. Miller, and A. Bland. 2007. Perceptions of Ohio engineers on the role of technology education in their preparation for a career in engineering. Ohio Northern University, Ada, $\mathrm{OH}$.

National Association of Secondary School Principals. 2004. Breaking ranks II: strategies for leading high school reform. The Education Alliance at Brown University, Providence, RI.

National Centers for Career and Technical Education. 2007. Exemplary program indicators. Available via <http://www. nccte.org/exemplary/appl y/2002EvaluationCriteria.pdf> [accessed June 22, 2007].

Ohio Department of Education. 2007. Career technical planning districts. Available via <https://webapp2.ode. state.oh.us/ctp

d_region/> [accessed June 26, 2007].

Ohio Department of Education. 2006. Ohio's K-12 mathematic academic content standards compared to national council of teachers of mathematics standards for school mathematics . Available via $<\mathrm{http} / / /$ www.ode.state.oh.us $>$ [accessed June 26, 2007].

Oregon State University. 1993. Integrated science, mathematics and technology curriculum series: integrated curricula grades 5-12, Oregon State University, Corvallis, OR.

Rockwell Automation. 2005. Arena training manual, Rockwell Automation, Sewickley, PA.

Southern Region Education Board. 2004. Using rigor, relevance and relationships to improve student achievement: how some schools do it. Southeast Region Education Board, Atlanta, GA.

Shibley, K. 2006. The state of Ohio's ninth graders. Ninth Grade make it or break it year retreat. Ohio Department of Education, Columbus, $\mathrm{OH}$.

Venezia, A., M. W. Kirst, and A. L. Antonio. 2003. Betraying the college dream: how disconnected $K-12$ and post-secondary education systems undermine student aspirations, Stanford University Bridge Project, The Stanford Institute for Higher Education Research, Stanford, CA.

\section{AUTHOR BIOGRAPHY}

BEVERLY BIEL KUCH is a Career Pathways Specialist in the Career Development Department of Cuyahoga Valley Career Center. After graduating from Cleveland State University with a Bachelor of Chemical Engineering degree, she held senior engineering positions at British Petroleum in Warrensvile Heights, Ohio. Among her responsibilities at CVCC are the identification, evaluation and implementation of innovative programming incorporating academic and career-technical content, focusing on mathematics, science and technology. 